\title{
Section 304 of the Internal Revenue Code: Unmasking Disguised Dividends in Related Corporation Transactions
}

Donald G. Kempf, Jr.

When two or more corporations are under common control, there is often a desire to extract cash or other property from one of the corporations without substantially reducing control over the combined corporate group. Minor differences in the form used to carry through essentially similar transactions which achieve this result can lead to major tax differences. On occasion, radically different and inconsistent views as to the tax consequences to be accorded a single transaction can exist simultaneously, each with seemingly sound statutory authority.

A hypothetical will illustrate some possible results. Assume that $A$ owns $80 \%$ of the stock of both corporations $X$ and $Y$, that both corporations have earnings and profits in excess of $\$ 60,000$, and that the $X$ stock held by $A$ has a basis of $\$ 75,000$ and a current fair market value of $\$ 100,000$. $A$ might extract cash from $Y$ by transferring his $X$ stock to $Y$ in return for $\$ 60,000$ in cash and stock of $Y$ valued at $\$ 40,000$. Viewed as a distribution of corporate property to a shareholder under sections 304 and $302(\mathrm{~d}),{ }^{1} A$ would have a $\$ 60,000$ dividend taxable as ordinary income. If, on the other hand, the transaction were treated as a section 351 exchange, $A$ would have a $\$ 25,000$ capital gain. Yet a third treatment of the transaction-viewing it as a corporate reorganization controlled by section $356(\mathrm{a})(2)$ - would leave $A$ with a $\$ 25,000$ dividend.

Extraction of cash from one of the corporations while surrendering insubstantial control could be accomplished by casting the transaction in still different forms. A sale, for example, of $X$ 's assets to $Y$ for cash and stock of $Y$, followed by a distribution of the cash and stock by $X$ to its shareholders, would appear on its face to be a (D) reorganization.

Donald G. Kempf, Jr. is a member of the Illinois Bar and is currently an Associate with Kirkland, Ellis, Hodson, Chaffetz \& Masters, Chicago, Illinois. He received his Bachelor of Arts degree from Villanova University in 1959 and his Bachelor of Laws degree from Harvard Law School in 1965. The author gratefully acknowledges the encouragement and advice of Professor Ernest J. Brown of the Harvard Law School and Michael Steinberg, Esq., of the Massachusetts Bar.

1 INT. REv. CODE of 1954, §§ 304, 302(d). [References to the Internal Revenue Code of 1954 will hereinafter be made by section number only.] 
This also could lead to a $\$ 25,000$ dividend under section $356(\mathrm{a})(2)$. Using still another route, $X$ could adopt a plan of complete liquidation and distribute its assets to its shareholders; $A$ would, in turn, sell the assets to $Y$ for cash. At first blush, this would appear to give $A$, in accordance with section $331(\mathrm{a})(1)$, a $\$ 25,000$ capital gain.

This article examines the impact of section 304 on the various ways by which a taxpayer may attempt to withdraw cash or other property from one of his controlled corporations without significantly reducing his control. Of primary concern is the attainment of judicial techniques and the suggestion of legislative changes which will more nearly achieve the goal of according similar tax treatment to transactions having similar economic effects. In the original hypothetical (where stock in $X$ was transfered to $Y$ for cash and stock of $Y$ ), the conclusion is that treatment under sections 304 and 302 (d) is more defensible than treatment under either section $356(a)(2)$ or section 351 and that, as between the latter two, section $356(a)(2)$ should prevail over section 351 . It is also concluded that, while liquidation-reincorporation will probably not enable the taxpayer to avoid section 304 treatment, the (D) reorganization can in all probability often be used to reduce substantially the impact of section 304.

The first part of this article is concerned with whether section 304 should apply to transactions involving related corporations, while the latter portion will consider the problems which arise in determining whether a section 304 transaction should receive capital gain or ordinary income treatment.

\section{The Legislative Framework}

\section{A. The Legislative and Judicial Background of Section 304}

When the 1939 Code was enacted, section $115(\mathrm{~g})^{2}$ treated a redemption by a corporation of its stock which was essentially equivalent to the distribution of a taxable dividend as a taxable dividend to the extent of accumulated earnings and profits. That certain transactions in some ways resembling redemptions and having somewhat the same effect were without the reach of section $115(\mathrm{~g})$ was brought into sharp focus in Rodman Wanamaker Trust. ${ }^{3}$ In that case John Wanamaker had established a trust of the stock of John Wanamaker, Philadelphia, at his death. Later, the trustees lacked liquid funds to meet the charges against the principal and did not wish to sell the stock to outsiders. During the period from 1941 through 1945, therefore, they transferred 100 shares of the stock annually to John Wanamaker, New York, a wholly owned

2 Int. Rev. Code of 1939, $\S 115(\mathrm{~g}), 53$ Stat. 48.

3 II T.C. 365 (1948), aff'd per curiam, 178 F.2d 10 (3d Cir. 1949). 
subsidiary, for book value and claimed a loss each year on the sale. The Commissioner asserted a deficiency under section 115(g). The Tax Court held that section $115(\mathrm{~g})$ was inapplicable on the ground that the acquisition by a subsidiary of the stock of its parent did not fit within the literal language of the statute requiring a redemption by a corporation of "its stock." 4 The court declined either to recast the transaction as a dividend from the subsidiary to the parent followed by a redemption by the parent or to disregard the corporate entity of the subsidiary. The result was that the trustees were able to withdraw a large amount of cash from the subsidiary without affecting their control over the parent.

In 1950, Congress added section $115(\mathrm{~g})(2)$ to the $1939 \mathrm{Code}^{5}$ in order to tax as dividends transactions which were cast in the Wanamaker pattern and which were "essentially equivalent to a taxable dividend." Commentators were quick to point out that the same tax-avoidance possibilities which had formerly existed in the parent-subsidiary situation continued to present themselves in the brother-sister relationship, ${ }^{6}$ where both the issuing corporation and the acquiring corporation were controlled by the same interests. ${ }^{7}$ This became evident in Emma Cramer. ${ }^{8}$ There the members of the Cramer family, either directly or

4 An analogy was made to Mead Corp. v. Commissioner, 116 F.2d 187 (3d Cir. 1940), which held that $\S 104$ of the Revenue Act of 1928 , ch. 852, \& 104, 45 Stat. 814, the predecessor of $\$ \$ 531-37$, dealing with the improper accumulation of earnings and profits, required that the corporation be availed of for the purpose of avoiding a tax on "its" shareholders and that, therefore, the section did not apply to accumulations by a subsidiary, even though the purpose was avoidance of a tax on the shareholders of the parent.

5 Revenue Act of 1950, ch. 994, § 209(a), 64 Stat. 932.

6 See, e.g., Bittker \& Redlich, Corporate Liquidations and the Income Tax, 5 TAX L. REv. 437, 479-80 (1950); Nolan, The Uncertain Treatment of Stock Redemptions: A Legislative Proposal, 65 HARv. L. REv. 255, 292 (1951).

7 This article will not consider the desirability, as an original matter, of treating as redemptions stock transfers between brother-sister corporations. It is sufficient to note that the Senate so doubted the wisdom of such treatment in 1950 that it eliminated a provision in the House bill which would have extended $\S 115(\mathrm{~g})(2)$ to cover this situation with the observation that "in that case it is not clear that the effect is the same as a redemption of the stock of the issuing corporation." S. REP. No. 2375, 81st Cong., 2d Sess. 43 (1950). For a more recent consideration see Terry, Section 304 of the Internal Revenue Code of 1954: Redemptions by Related Corporations, 3 WM. \& MARY L. REv. 457, 466-67, 481-82 (1962). "It is not at all clear that the Congress, the Revenue Service, tax practitioners in general nor the Subchapter G Advisory Group have developed a satisfactory theoretical basis for dividend consequences in brother-sister redemption cases. Ever since the Senate Finance Committee took the position in 1950 that it was not clear that brothersister redemptions were the equivalent of dividends, there seems to have been a cautious approach to the mechanics of the statute. It is submitted that this cautious attitude is the result of the absence of any consistent, clear-cut theory on what are 'the economic realities' of brother-sister redemptions." $I d$. at 481 . Section 1239 reflects, to a limited extent, consideration of the same policy judgments inherent in $\S 304(a)(1)$.

820 T.C. 679 (1953). 
as beneficiaries under trusts, held all of the stock of four corporations. Between November, 1946 and October, 1947, the enterprises were integrated by having one corporation purchase all the outstanding stock of the other three corporations and then liquidate them. The Tax Court held that the decision in Wanamaker precluded the application of section $115(\mathrm{~g})$ and held further that section $115(\mathrm{a})^{9}$ could not be extended to embrace the transaction on the ground that to read section 115 (a) so broadly would leave section 115 (g) as mere surplusage and that, therefore, Congress must have intended a narrower scope for section $115(\mathrm{a}) \cdot .^{10}$ The court also rejected a suggestion that the cash portion of the distribution be taxed as "boot" incident to a reorganization. ${ }^{11}$

The Treasury refused to acquiesce ${ }^{12}$ in these decisions and continued to insist that such distributions were taxable as dividends under section 115(a). In 1959, however, after losing a series of cases ${ }^{13}$ in which the courts specifically declined invitations to overrule Wanamaker and Cramer and in which emphasis was placed on the additional factor that section 304(a)(1) had been enacted to operate prospectively only, the Treasury indicated its acquiescence. ${ }^{14}$ The Commissioner's lone success under the 1939 Code was a case wherein the stock sale was an obvious sham which the Tax Court disregarded. ${ }^{15}$

One of the objectives of the draftsmen of the Internal Revenue Code of 1954 was to prevent tax avoidance by "sales of stock between corporations owned by the same interests."16 Accordingly, section 304, the successor to section $115(\mathrm{~g})(2)$ of the 1939 Code, was designed to reach brother-sister transactions as well as parent-subsidiary transactions. As the report of the House Committee noted:

9 Int. Rev. Code of 1939, $\$ 115(a), 53$ Stat. 46, as amended: "The term 'dividend' . . means any distribution made by a corporation to its shareholders . ..."

1020 T.C. at 684 .

11 Ibid. The possibility of treating the cash portion of the distribution as "boot" incident to a reorganization is discussed in the text accompanying notes 76-98 infra.

12 Rev. Rul. 55-15, 1955-1 Cum. BuLl. 361.

13 Commissioner v. Pope, 239 F.2d 881 (1st Gir. 1957); Busch v. United States, 58-1 U.S. Tax Cas. 68013 (S.D. Cal. 1958); Trianon Hotel Co., 30 T.C. 156 (1958), appeal dismissed per stipulation, 6th Cir., Aug. 22, 1958, acq., 1959-1 Cum. Bull. 5; Westerhaus Co., 16 C.CH Tax Ct. Mem. 958 (1957). See also Brown v. United States, 180 F. Supp. 833 (E.D. Mich. 1960); Tom Coke Connally, 20 CCH Tax Ct. Mem. 1613 (1961).

14 Rev. Rul. 59-97, 1959-1 Cum. BuL.. 684. The citation of Commissioner v. Liddon, 230 F.2d 304 (6th Cir.), cert. denied, 352 U.S. 824 (1956), as an example of the type of case in this area where dividend treatment will continue to be accorded is not without significance and is discussed in the text accompanying notes 78-79, 84-87, 94 infra.

15 Sam Gold, 17 CCH Tax Ct. Mem. 6 (1958).

16 S. Rep. No. 1622, 83d Cong., 2d Sess. 45 (1954). Compare H.R. REP. No. 1337, 83d Cong., 2d Sess. 37 (1954) ("where the effect of the sale is in reality the distribution of a dividend, such sale will be taxed as such"). 
Subsection (a) sets forth the general rule of the section by providing that in any case in which one or more individuals who are in control of two or more corporations sell the stock of one of the corporations to another of such corporations the proceeds of such sale shall be considered to be an amount distributed in redemption of the stock of the corporation which purchased the stock. ${ }^{17}$

The reach of section 304 was extended somewhat in both cases by the insertion of a new provision, section 318 , which established rules relating to the constructive ownership of stock.

\section{B. Application of Section 304}

Section $304(a)(1)^{18}$ provides that for purposes of section 302, relating to distributions in redemption of stock, if a person is in control of each of two corporations, and, in return for property, one of the corporations acquires stock in the other corporation from that person, the property is treated as a distribution in redemption of the stock of the acquiring corporation. Section $304(c)^{19}$ establishes a $50 \%$ control test which is to be determined in light of the constructive ownership rules in section 318(a). ${ }^{20}$ Section 302 (d) ${ }^{21}$ states that stock redemptions, except as otherwise provided in subchapter $\mathrm{C}$, shall be treated as distributions of property to which section 301 applies unless treated otherwise by section

17 H.R. REP. No. 1337, 83d Cong., 2d Sess. A79 (1954). Compare S. REP. No. 1622, 83d Cong., 2d Sess. 239 (1954) ("The effect of the operation of section 304 is to characterize as redemptions distributions which are cast in the form of sales.").

18 "For purposes of sections 302 and 303 , if-

(A) One or more persons are in control of each of two corporations, and

(B) in return for property, one of the corporations acquires stock in the other corporation from the person (or persons) so in control,

then (unless paragraph (2) applies) such property shall be treated as a distribution in redemption of the stock of the corporation acquiring such stock."

19 "(l) For purposes of this section, control means the ownership of stock possessing at least 50 percent of the total combined voting power of all classes of stock entitled to vote, or at least 50 percent of the total value of shares of all classes of stock. . . .

"(2) Section 318(a) (relating to the constructive ownership of stock) shall apply for purposes of determining control under paragraph (1). For purposes of the preceding sentence, sections $318(a)(2)(C)$ and $318(a)(3)(C)$ shall be applied without regard to the 50 percent limitation contained therein."

20 The advisory group on subchapter $\mathrm{C}$ has recommended that, for purposes of $\S 304$, the $50 \%$ limitation contained in $\S 318(\mathrm{a})(2)(\mathrm{C})$ and $\S 318(\mathrm{a})(3)(\mathrm{C})$ be replaced. with a $5 \%$ limitation. The advisory group felt that a $5 \%$ limitation would be sufficiently low so as not to give rise to tax avoidance. Advisory Group on SUbGhapter C OF THE INTERNAL Revenue Code of 1954, Revised Report on Corporate Distributions ANd Adjustments 13, 26 (1958) [hereinafter cited as SUBCHAPTER G Advisory Group REvised REPORT].

21 "Except as otherwise provided in this subchapter, if a corporation redeems its stock (within the meaning of section $317(b)$ ), and if subsection (a) of this section does not apply, such redemption shall be treated as a distribution of property to which section 301 applies." 
302(a). ${ }^{22}$ Section 302 (a) treats distributions in redemptions which qualify under sections $302(\mathrm{~b})(1)$, (2), or (3) as payments in exchange for stock. Sections 302(b)(2) and (3) are specific "safe harbors" applicable only when the redemption is substantially disproportionate to stock ownership or when it terminates the interest of the particular shareholder. A redemption qualifies under section $302(b)(1)$ if it is not "essentially equivalent to a dividend." Section $301(a)^{23}$ states that, except as otherwise indicated in chapter 1 of the Code, a distribution of property ${ }^{24}$ made by a corporation to a shareholder with respect to its stock is to be treated in accordance with section $301(\mathrm{c}) .{ }^{25}$ The latter section requires the inclusion in gross income of that portion of the distribution which constitutes a dividend. ${ }^{26}$ In a brother-sister stock transfer to which section 304 applies, the acquiring corporation is to treat the stock which it receives in the related corporation as a contribution to capital, ${ }^{27}$ the transaction is tested under section 302 (b) by reference to the stock of the issuing corporation without regard to the $50 \%$ limitation contained in sections $318(\mathrm{a})(2)(\mathrm{C})$ and $318(\mathrm{a})(3)(\mathrm{C}),{ }^{28}$ and dividend treatment is accorded solely by reference to the earnings and profits of the acquiring corporation. ${ }^{20}$

The application of section 304(a)(1) may be illustrated by the following example. $A$ owns $75 \%$ of the stock of both corporations $X$ and $Y$. He transfers his stock in $X$ to $Y$ and receives cash from $Y$. The $X$ stock

22 "If a corporation redeems its stock (within the meaning of section 317(b)), and if paragraph (1), (2), (3), or (4) of subsection (b) applies, such redemption shall be treated as a distribution in part or full payment in exchange for the stock."

23 "Except as otherwise provided in this chapter, a distribution of property (as defined in section 317 (a)) made by a corporation to a shareholder with respect to its stock shall be treated in the manner provided in subsection (c)."

24 The term "property" is defined in $\$ 317(\mathrm{a})$.

25 "In the case of a distribution to which subsection (a) applies-(1) . . That portion of the distribution which is a dividend (as defined in section 316) shall be included in gross income."

20 The term "dividend" is defined in $\S 316$.

27 Section 304(a)(1): “. . . In any such case, the stock so acquired shall be treated as having been transferred by the person from whom acquired, and as having been received by the corporation acquiring it, as a contribution to the capital of such corporation."

28 Section 304(b)(1): "In the case of any acquisition of stock to which subsection (a) of this section applies, determinations as to whether the acquisition is, by reason of section 302(b), to be treated as a distribution in part or full payment in exchange for the stock shall be made by reference to the stock of the issuing corporation. In applying section 318(a) (relating to constructive ownership of stock) with respect to section 302(b) for purposes of this paragraph, sections $318(a)(2)(C)$ and $318(a)(3)(C)$ shall be applied without regard to the 50 percent limitation contained therein."

29 Section 304(b)(2)(A): "In the case of any acquisition of stock to which paragraph (1) ... of subsection (a) of this section applies, the determination of the amount which is a dividend shall be made solely by reference to the earnings and profits of the acquiring corporation." 
which $A$ transferred is treated by $Y$ as a contribution to capital, and the cash which $A$ receives from $Y$ is treated as a distribution in redemption of $Y$ stock. This allows that portion of the transaction to be analyzed under section 302. Because the transaction is not protected by one of the "safe harbors," the focus of the examination will be a determination whether the cash distribution is "essentially equivalent to a dividend." If it is not, it will be treated as a distribution in exchange for the stock under section 302(a); if it is, it will be taxed as a dividend under section $301(c) .{ }^{30}$

\section{Treatment of Asset Withdrawals Accompanied by StOck Transfers}

\section{A. The Conflict with Section 351(b): The Haserot Case}

Immediately prior to February 18, 1958, Henry McK. Haserot, the taxpayer, was the principal shareholder of the Northport Cherry Factory, Inc. (Northport), the Gypsum Canning Company (Gypsum), and the Haserot Company, three closely held corporations engaged in various phases of the wholesale food business. ${ }^{31}$ On February 14, 1958, the taxpayer offered to transfer to the Haserot Company his Northport and Gypsum stock in return for 2,432 shares of the Haserot Company's authorized but unissued stock and $\$ 64,850 .^{32}$ On February 18, 1958, the company's board of directors accepted the taxpayer's offer. ${ }^{33}$ As of that date, the Haserot Company had accumulated earnings and profits in excess of $\$ 113,490$. The cash portion was credited to the taxpayer's account on the company's books, and the 2,432 shares were issued to his

30 For other examples see Treas. Reg. $\$ 1.304-2$ (c) (1955), as amended, T.D. 6533, 1961-1 Cum. BulL. 70. It should be noted that the addition of $\$ 318(\mathrm{a})(5)(\mathrm{C})$, eliminating "sidewise" attribution, Pub. L. No. 88-554, § 4(a), 78 Stat. 761 (1964), to the Code changes the treatment to be accorded the distribution in example (I) of the Regulation. The transaction now appears to qualify for the "safe harbor" of $\S 302(b)(2)$. See generally Ringel, Surrey \& Warren, Attribution of Stock Ownership in the Internal Revenue Code, 72 HARv. L. REv. 209, 260-65 (1958).

31 The summary of these transactions is taken from the Tax Court findings of fact in Henry McK. Haserot, 41 T.C. 562 (1964), appeal docketed, No. 16184, 6th Cir., July 7, 1964.

32 The shares of Northport and Gypsum stock had been held for more than six months, had an aggregate adjusted basis of $\$ 72,905.15$, and were capital assets in Haserot's hands.

33 Immediately prior to February 18, 1958, the outstanding shares of Northport and Gypsum were owned as follows:

\begin{tabular}{llc}
\hline \multicolumn{1}{c}{ OWNER } & NORTHPORT & GYPSUM \\
\hline Haserot & 1,999 shares & 4,486 shares \\
The Haserot Company & 1,250 & 2,022 \\
Gypsum & 1,312 & $-0-$ \\
Mabel Carnes & 1 & 74 \\
Total & $\overline{4,562}$ shares & $\mathbf{6 , 5 8 2}$ shares \\
\hline
\end{tabular}


son, pursuant to the taxpayer's instructions, as a gift. ${ }^{34}$ The taxpayer planned to put his own Haserot stock in trust upon his death and believed that the gift of the additional Haserot shares would enable his son to maintain voting control of the company thereafter.

In planning the transaction, the Haserot Company preferred to have direct stock ownership of Northport and Gypsum for bona fide business reasons. The taxpayer did not consult with counsel and was unaware that the stock transfer involved either tax problems or tax advantages. His return omitted any reference to the transaction. The Commissioner served him with a deficiency notice which he appealed to the Tax Court. There, the argument centered on the treatment of the cash credit. The Commissioner conceded that the stock received did not constitute taxable income, but insisted that the full amount of the cash credit was a taxable dividend under sections 304, 302, and 301 of the 1954 Code. The taxpayer claimed that the transaction qualified under section 351 and that, therefore, only his gain of $\$ 40,585^{35}$ was taxable, and only as a long-term capital gain. He contended, in the alternative, that if section 304 were applicable, the gain was a capital gain under section 302(a) on the theory that the distribution was "not essentially equivalent to a dividend." 36

The Tax Court agreed with the taxpayer's contention ${ }^{37}$ that the "except as otherwise provided" clauses of sections 301(a) and 302(d) eliminated the possibility of dividend treatment and held that their effect was to cause the payment by the Haserot Company to be treated as a payment in exchange for the Northport and Gypsum stock, giving rise to a capital gain. ${ }^{38}$ The court recognized that the transaction came within the literal language of both sections 351 and 304:

34 Immediately following the transaction and the gift to Haserot's son, the outstanding shares of the Haserot Company were owned as follows:

\begin{tabular}{lc}
\hline \multicolumn{1}{c}{ OWNER } \\
\hline Haserot & 29,188 shares \\
Henry M. Haserot, Jr. (son) & 3,455 \\
18 others & 2,803 \\
Total & $\frac{35,446}{35}$ shares \\
\hline
\end{tabular}

35 Amount realized $(\$ 113,490)$ less adjusted basis $(\$ 72,905)$.

36 Section 302(b)(1).

37 See Brief for Petitioner, pp. 26-28, Henry McK. Haserot, 41 T.C. 562 (1964); Reply Brief for Petitioner, pp. 13-16. Hereafter, references to briefs for petitioners or respondents without further case identification can be presumed to refer to the Haserot case, either in the Tax Court or in the Sixth Circuit, where a decision has not yet been rendered. Of course, in the Tax Court the taxpayer was the petitioner and the Commissioner was the respondent. These roles are reversed in the appeal to the Sixth Circuit.

38 Henry McK. Haserot, 4I T.C. 562 (1964), appeal docketed, No. 16184, 6th Cir., July $7,1964$. 
For purposes of section $351(\mathrm{a}),(\mathrm{b})$, there was a transfer of property (Northport and Gypsum stock) in exchange for stock in a corporation (Company) that was controlled (owned at least 80 percent of the stock) immediately thereafter by the transferor (petitioner). For purposes of section 304(a)(1), one person (petitioner) was in control (direct or constructive ownership of at least 50 percent of the stock) of three corporations (Northport, Gypsum, and Company) and in return for property (money) one of the corporations (Company) acquired stock in the other corporations (Northport and Gypsum) from the person in control (petitioner). ${ }^{39}$

The court believed, however, that the "except as otherwise provided" clauses indicated a congressional policy decision that dividend treatment result from the application of section 302 only when no other provision in the relevant parts of the Code called for other treatment. Since section 351 was, by its terms, applicable and contained no clause of limitation, it was held to govern. ${ }^{40}$ In addition to so construing the relevant Code provisions, the court: (1) stated that Congress probably had not given specific thought to the result that should obtain in factual patterns such as Haserot, (2) recognized that under its interpretation brother-sister stock transfers might be so arranged that they would be subject to dividend treatment only if the controlling party owned at least $50 \%$ but less than $80 \%$ control of the acquiring corporation, and (3) held inapplicable previous cases which had considered conflicts between section 351 and other sections of the Code on the ground that the provisions under consideration in those cases did not contain clauses indicating that in certain situations they were to give way to other Code provisions. While recognizing that the legislative pattern applied to the Haserot case might be characterized as eccentric, the court concluded that, "nevertheless, the language of the statute compels, in our view, the result here reached." 41

While not expressly so stated, the position of the Commissioner in the Tax Court appears to have been that the Haserot transaction fell within the literal language of both sections 351 and $304 .{ }^{42}$ Faced with this conflict, the Commissioner's theory was that policy and precedent favored the application of section $304 . .^{43}$ The taxpayer, however, insisted that

39 Id. at 568-69. (Footnotes omitted.)

$40 \mathrm{Id}$. at 570.

$41 \mathrm{Id}$. at 572 .

42 See Brief for Respondent, pp. 13-14. The taxpayer also thought this to be the Commissioner's position. Reply Brief for Petitioner, p. 5. ("Petitioner and this Court are entitled to proceed on the premise that Respondent now concedes that the transaction in question did in fact meet all the requirements of Section 351.") (All italicized in original.) 43 See Brief for Respondent, pp. 10-14; Reply Brief for Respondent, p. 4. 
any conflict between the sections was a false one. While he agreed with the Commissioner's apparent concession on the applicability of section 351,44 he argued at length against the applicability of section $304 .{ }^{45}$ The taxpayer interpreted section 302(d) as calling for section 301 treatment only in cases where it was not "otherwise provided in this subchapter." In turn, he interpreted section 301(a) as invoking the dividend treatment of section 301 (c) only in cases where it was not "otherwise provided in this chapter." Section 351, he argued, provided otherwise. Since it contained no clause of limitation, he concluded, no conflict existed and section 351 alone governed the transaction. As evidence of the fact that the "except as otherwise provided" clause of section 301(a) was intended to cover section 351 transactions, the taxpayer noted the cross reference to section 351 in the predecessor of section $301(\mathrm{~g})(3){ }^{46}$ The Commissioner countered summarily that section 7806 (a), stating that cross references shall be given no legal effect, rendered both "except as otherwise provided" clauses and the cross reference in the predecessor of section $301(\mathrm{~g})(3)$ without significance. ${ }^{47}$ The Tax Court agreed with the taxpayer's interpretation; ${ }^{48}$ commentators have concurred. ${ }^{49}$

In his appeal to the Sixth Circuit, the Commissioner has taken the position that there is, indeed, a false conflict. His conclusion, however, unlike that of the taxpayer and the Tax Court, is that section 304 alone can govern the transaction:

Section 351 applies only when property is transferred to a controlled corporation "in exchange" for the corporation's shares (a true exchange transaction); and since Section 304 specifically provides that a situation described by Section 304 (and the instant case presents such a situation) will not be considered as an exchange transaction, but will be fragmented into a redemption and a contribution to capital, Section 351 does not apply at all.

44 See Brief for Petitioner, pp. 16-20; Reply Brief for Petitioner, pp. 5-6.

45 See Brief for Petitioner, pp. 25-35; Reply Brief for Petitioner, pp. 6-20.

46 Section 301(f)(3) (redesignated by 76 Stat. 5 (1962)).

47 See Reply Brief for Respondent, p. 5.

48 In concluding that $\S 304$ could not be avoided by combining stock with cash in cases where the taxpayer controlled less than $80 \%$ of the stock in the acquiring corporation, the court appears to have rejected sub silentio an alternative argument by the taxpayer that $\S 304$ only applies when the stock acquisition was solely for property. This question has also been raised by the taxpayer in his brief to the Sixth Circuit. See Brief for Respondent, pp. 14,68 .

49 Warren \& Antoine, Comment on Haserot, 1964 CCH Fed. TAxation: Current L. \& Practice 975 ("The court seems to reach the right result as a matter of statutory interpretation."); Recent Developments, IRC Section 351 Bars Dividend Treatment of "Boot" Paid in Redemption of Brother Corporation's Stock, 64 Colum. L. Rev. 1151, 1156 (1964) ("As a matter of statutory construction, the conclusion in the instant case seems correct ...."). 
Section 304(a) characterizes the Northport and Gypsum stock as a contribution to capital and not as an exchange. Section 351(a) could not possibly apply to this case. . . .

But there is an infirmity in the Commissioner's position; as an original matter, it is as easy to say that section 351 "characterizes" the transaction as an exchange which precludes the application of section 304 , as it is to say that section 304 "characterizes" the transaction as a redemption which precludes the application of section 351.51 This was, in fact, a contention put forth by the taxpayer in the Tax Court ${ }^{52}$ and repeated in his brief to the Sixth Circuit. ${ }^{53}$

More helpful to a solution of the purported 304-351 conflict is the Commissioner's argument that the Tax Court erred in concluding that "the very words of [sections $302(\mathrm{~d})$ and $301(\mathrm{a})$ ] . . preclude dividend treatment in this case." ${ }^{4}$ The Commissioner asserts that the "except as otherwise provided" language of section 302(d) refers on its face only to those other sections of subchapter $\mathrm{C}$ which specifically deal with redemptions, such as sections $303,331,346$, and 355 . The statute is interpreted as reading: In a brother-sister stock transaction, a distribution to which section 302(a) does not apply is to be treated under section 301 unless the transaction as a whole is also capable of being viewed as a redemption (within the meaning of section $317(\mathrm{~b})$ ) and unless one of the other sections dealing with redemptions treats the transaction differently. Accordingly, he concludes that section 351 cannot fall within the limiting clause because it is an exchange provision, not a redemption provision. ${ }^{55}$ Similarly, the "except as otherwise provided" language in section 301 (a) is viewed as being limited to distributions such as those spelled out in sections 116, 301(e), 302(a), 303, 305, 331, 346, 355, 1031(c), and 1111. Again, since a 351 transaction is characterized as an exchange, and not a distribution, it does not fall within the terms of the "except as otherwise provided" clause. ${ }^{56}$ The Commissioner also states that if the "except as otherwise provided in this chapter" clause of section 301(a) were given the sweep accorded it by the Tax Court, section

50 Brief for Petitioner, pp. 18-19.

51 Adding to the difficulty is the fact that $\$ 304$ itself limits the characterization of the distribution to "the purposes of sections 302 and 303" and, therefore, appears not to preclude alternative characterizations for the purposes of other sections. The taxpayer was quick to call attention to this fact. See Brief for Respondent, pp. 41-42.

52 See Reply Brief for Petitioner, pp. 9-12, where the taxpayer argues that since \$ 351 characterizes the transaction as an exchange, $\S 304$, which is applicable only to sales, cannot apply.

53 See Brief for Respondent, pp. 60, 63-69.

5441 T.G. at $\mathbf{5 7 0 .}$

55 See Brief for Petitioner, p. 21.

56 See Brief for Petitioner, pp. 21-22. 
304(a) would never be operative because of the existence "in this chapter" of sections 1001, 1002, 1201, 1202, 1221, and 1223(3), which would treat as the sale or exchange of a capital asset the transfer of stock in one controlled corporation to another controlled corporation in exchange solely for cash. ${ }^{57}$

That the Commissioner is correct in his interpretation of the limiting clauses of sections 302 (d) and 301(a) as referring to other redemptions and other distributions, respectively, seems clear. While such a reading may not be compelled by the language, it is certainly consistent with it. Indeed, it is perhaps the most natural reading of the sections. Two other factors commend such a reading. First, it seems to strike the most reasonable balance between the all-inclusiveness argued for by the taxpayer and adopted by the Tax Court and the narrow reading which would limit the clauses to those sections such as 331(b) and 346 (c) which specifically state that sections 301 and 302 are not to govern a particular transaction. Such a midway position is more likely to have been intended by Congress than either of the problem-raising extremes suggested. Secondly, such a reading would appear to avoid the automatic carryover of section 351 into sections 302 (d) and 301(a), which even the court recognized as yielding an eccentric result, and enable the transaction to be evaluated as one presenting a true conflict between the policies of sections 304 and 351 .

Less clear, and not discussed in the Commissioner's brief, is whether the Haserot transaction, which fits within the language of section 351, may also be characterized as either a redemption or a distribution for the purposes of sections 302 (d) or 301 (a) respectively. ${ }^{58}$ If it may, those clauses would continue to invoke section 351 treatment for the transaction even under the Commissioner's interpretation.

The redemptions to which the limiting clause in section 302(d) refers are given content by section 317 . Section 317 (b) provides that for purposes of sections 301 through $318^{59}$ "stock shall be treated as redeemed by a corporation if the corporation acquires its stock from a shareholder in exchange for property ...." Section 317(a) states that property "does

57 See Brief for Petitioner, pp. 20-22. The opinions expressed by the Tax Court concerning the meaning of the limiting clause of $\S 301$ (a) would appear to be dictum. Construing the limiting clause of $\S 302$ (d) to encompass $\S 351$ within its scope would eliminate the necessity of interpreting the limiting clause of $\S 301$ (a).

58 The taxpayer in his brief to the Sixth Circuit has not attempted so to characterize the transaction; rather he urges that the Tax Court was correct in its all-inclusive view of the "except as otherwise provided" clauses. See Brief for Respondent, pp. 50-51, 54-56, $59,61-63$.

59 The advisory group on subchapter $G$ has recommended that the definition apply throughout subchapter C. SUBCHAPTER C ADVISORY GROUP REvised REPORT 24. 
not include stock in the corporation making the distribution." redemptions, as defined in section $317(\mathrm{~b})$, are not limited to exchanges solely for property, ${ }^{61}$ it would appear that the additional consideration of the Haserot Company stock, which does not qualify as property under section 317(a), does not prevent the Haserot transfer from being classified as a redemption under section $317(\mathrm{~b})$. The taxpayer would then argue that this transaction is a redemption, but one for which section 351 provides specific tax treatment and thus one to which the limiting clause of section $302(d)$ refers.

An additional obstacle to the success of this argument is that section 317(b) requires an acquisition by a corporation of "its stock." The taxpayer might contend that this requirement is satisfied by the fact that section 304 itself characterizes such a sale as a redemption by the acquiring corporation of its stock. Upon close examination, however, this argument will not stand. Section 304 provides only that the distribution shall be treated as one in redemption of stock, not that the entire transaction shall be treated as a redemption. Even this fiction is narrowly limited to the "purpose of sections 302 and 303."62 Thus limited, section 304 neither creates a new form of redemption by its own terms nor broadens the inclusiveness of the term "redemption" in either section 317 (b) or 302 .

Since the "except as otherwise provided" clause of section 302(d), when interpreted most reasonably, refers to other sections of the Code only when those sections call for an alternative treatment of redemptions as the term is defined in section $317(\mathrm{~b})$ and since a section 351 transaction cannot be viewed as a redemption because it is not within the definition of that term in section 317(b), it would seem impossible to fit the Haserot transaction within the definition of a redemption for purposes of the "except as otherwise provided" clause of section 302(d).

It is more difficult to ascertain the distributions to which the limiting clause of section 301(a) refers. Nowhere in the Code is distribution defined. Without express statutory authority, the Regulations ${ }^{63}$ indicate that certain distributions incident to section 351 (a) transactions are to be taxed in accordance with section 301 when they have the effect of

co It is presumably because of this restrictive definition of property and because $\S 302(d)$ subjects only such property to $\S 30 \mathrm{I}$ treatment that the Commissioner conceded that the stock which Haserot received in the transaction was not taxable.

61 Compare $\$ 351$ (a) ("solely in exchange for stock or securities"); $\$ 354$ (a)(1) ("solely for stock or securities"); $\S 368(a)(1)(B)$ ("solely for all or part of its voting stock"); $\$ 368(a)(1)(C)$ ("solely for all or part of its voting stock"). See also note 48 supra.

62 Section 304(a)(1).

63 Treas. Reg. § 1.351-2(d) (1955). Compare Treas. Reg. 1.301-1(l) (1955). Doubts as to the validity of the latter are expressed in Lane, The Reincorporation Game: Have the Ground Rules Really Changed?, 77 HaRv. L. REv. 1218, 1227 (1964). 
the distribution of a taxable dividend. The regulation could be viewed both as supporting and as weakening the Commissioner's position. On the one hand, it reflects a long standing belief at the Treasury that in some situations where sections 301 and 351 conflict, the former dominates. ${ }^{64}$ On the other hand, the regulation specifically refers to a "distribution" incident to a section $35 \mathrm{l}$ transaction, weakening the Commissioner's present contention that an exchange pursuant to a section 351 transaction cannot be viewed as a distribution to which the limiting clause of section 301(a) refers. The Commissioner's present position would have to be that the word "distribution" in the regulation is the result of poor drafting, is not binding on him in any event, and should not be read into the statute itself in view of the specific use of the word "distribution" by Congress in other sections when it wished that term to apply.

While somewhat overstated, ${ }^{65}$ the observation that a failure to interpret the term "distribution" in light of provisions such as section 304 would have the effect of reading those provisions out of the Code presents a forceful argument in support of the Commissioner's view that the distributions to which the "except as otherwise provided" clause of section 301 (a) refers should be interpreted to include only those receipts which are specifically characterized as distributions by other sections of the Code.

The cross reference in section $301(\mathrm{~g})(3)$ - "for distributions in corporate organizations and reorganizations, see part III (sec. $35 \mathrm{I}$ and following)"-would appear upon closer examination not to refer specifically to section 351 itself. More accurately, the reference is to part III of subchapter $\mathrm{C}$. The subsequent reference to section 351 is merely to indicate where part III begins.

While interpreting the "except as otherwise provided" clauses of both sections 301 (a) and 302(d) in this way does not determine whether

64 While the regulation could not be used directly in Haserot since it refers to transfers under $\$$ 351(a) where stock only is received, it would appear to be useful for purposes of attacking analogous situations arising under $\$ 351(\mathrm{~b})$. See BrrTKER, FEDERAL INCONE TAXAtION OF CORPorations AND Shareholders 105-06 (1959).

However, the validity of the regulation is doubtful; the Tax Court did not discuss it. The Commissioner neither cited it nor contended that were $\$ 351$ held applicable it would still be possible to tax a portion of the distribution as a dividend. Rather, he conceded in the Tax Court that the application of $\S 351$ would lead to capital gain treatment. Reply Brief for Respondent, p. 4. In view of the Commissioner's contention that the distribution was "essentially equivalent to a dividend," this concession indicates that there is doubt as to the validity of the regulation even in the opinion of the Treasury.

65 Because of the "except as otherwise provided in this subtitle" clause in $\S 1002$, the long reach which the Tax Court gave to the limiting clause of $\S 301$ (a) would not read $\S 304$ out of the Code. It would, however, create an undesirable conflict between the two sections in situations where Congress most certainly intended $\S 304$ to govern. 
the transaction should be accorded section 304 or section 351 treatment, it does open the door to a solution. The above interpretation of the limiting clauses shows that, contrary to the view of the Tax Court, sections 304 and 351 truly conflict. Precedent and policy are now not only relevant but dispositive of the case.

Policy favors the application of section 304 to the Haserot transaction. National Securities Corp. v. Commissioner ${ }^{66}$ and Rooney v. United States $^{67}$ illustrate that section 351 will give way where its literal application tends to frustrate another section of the Code. ${ }^{68}$ The Tax Court itself characterized as eccentric a result in which $50 \%$ control leads to dividend treatment whereas "greater control (with concomitant greater power for mischief) may confer the benefits of capital gain treatment."69 The specificity of the sections involved, as applied to the Haserot transaction, also lends support to the application of section 304 treatment. While the form of the transaction appears to fit more easily within the terms of section 351 than those of section 304, where the draftsmen apparently did not consider the possibility of the acquiring corporation issuing some of its own stock as a part of the transaction, the economic effects of the transaction fit more comfortably within the narrow group of transactions which section 304 was designed to curtail than within the broad range of transactions section 351 was designed to permit. Also suggesting section 304 treatment is the fact that it is the more recent of the two sections, and thus, presumably, represents the legislative intent concerning all transactions within the purview of section 304, prior inconsistent sections notwithstanding.

Further analysis of the stock aspect of the Haserot transaction, upon which any argument for section 351 treatment must rest, reveals an additional reason for invoking the policy embodied in section 304. As the percentage of ownership of a corporation by a shareholder increases, the significance of additional shares in the corporation correspondingly decreases. Where a shareholder, for example, owns $100 \%$ of a corporation, additional shares issued to him in a sale of property by him to the corporation do not affect his equity interest at all, since he already owns all of the corporation's outstanding stock. It is obvious that the value of any shares received in the transaction comes only from a dilution in the value of the previously issued shares. ${ }^{70}$

66137 F.2d 600 (3d Cir.), cert. denied, 320 U.S. 794 (1943).

67305 F.2d 681 (9th Cir. 1962).

68 In both cases the conflict was between $\$ \S 351$ and 482 (or the predecessors thereof). 6941 T.C. at 570.

70 An argument could be framed that, when we look to the insubstantial real value of the stock issued in the transaction, the stock fails to pass the de minimis hurdle and thus the transaction fails to qualify under $\S 351$ at all. Such a contention proves too much, for the real value of stock issued in $\S 351$ transactions is often slight. Its main function is 
Such a situation existed in the Haserot transaction, where the taxpayer controlled over $90 \%$ of the stock. The 2,432 shares received by Haserot in the transaction were valued by the Commissioner at $\$ 48,640$ (\$20 per share). But it is most probable that much of this value consisted of dilution in the value of other shares in the corporation. If we suppose the total value of the enterprise to be $\$ 708,920,{ }^{71}$ the net value of the increased stock ownership to Haserot was insubstantial. Before the transaction Haserot controlled ${ }^{72} 30,211$ of the corporation's 33,014 shares or approximately $91.5 \%$. Upon completion of the transaction, he controlled 32,643 of the corporation's 35,446 shares or approximately 92.1\%. Thus, the shares received in the transaction increased Haserot's control of the corporation by a rather insubstantial $0.6 \%$. It would appear that, were no shares issued in the transaction, the total value of Haserot's stock would have been $\$ 648,730.30 .^{73}$ With the receipt of the additional shares, however, the total value of Haserot's stock appears to have been $\$ 652,860.00 .{ }^{74}$ Thus, the real value of the shares issued to Haserot in the transaction appears to be an insubstantial $\$ 4,129.70$.

It is clear that section 351 treatment in such transactions is predicated solely on the inclusion of a stock transfer having little economic significance. In the Haserot transaction, for example, the taxpayer extracted $\$ 64,850$ from the corporations while surrendering no voting power and an equity interest of but $\$ 8,974.57^{75}$ in the shares which he transferred in the transaction. These are the economically significant elementsthe extraction of a large amount of cash and no substantial change in the taxpayer's control-and they point to section 304 policy and treatment.

\section{B. Possible Treatment as a Reorganization Under Section 356(a)(2)}

If "boot" is treated differently under sections $302(\mathrm{~d})$ and $351(\mathrm{~b})$, it is treated still a third way under section $356(a)(2)$ when incident to certain

usually to insure that the holdings of the transferor of the property to the corporation reflect in full the net increase in the assets of the corporation arising from the transaction. That the real value of the stock is most often slight, however, does not prevent focusing upon that fact when the question presented is whether the policy of $\S 304$ or that of $\S 351$ should govern in a situation within the literal language of both sections. Compare $\S 1239$.

$\tau 1 \$ 20 \times 35,446$.

72 Section 318(a) has been used throughout in making these computations. Without \$ 318(a), Haserot's stock ownership would be increased from $88.4 \%$ to $89.2 \%$ by the transaction.

$73 \$ 708,920 \times 30,211 / 33,014$.

$74 \$ 708,920 \times 32,643 / 35,446$.

$75 \$ 113,490 \times 2,803 / 35,446$. The computation assumes that the purchase price represented the fair market value of the Northport and Gypsum stock. At no time did the Commissioner contend otherwise. 
reorganizations. Given this situation, the possibility exists in future transactions following the Haserot pattern that the Commissioner, should section 304 be held inapplicable, or the taxpayer, should section 351 be held inapplicable, will try to characterize the transaction as a reorganization. ${ }^{76}$ Such a contention would not be novel in the field of brother-sister stock transactions. The Commissioner so argued in a brother-sister transaction which arose before the effective date of section 304(a)(1), but the Tax Court rejected the argument. ${ }^{77}$ The citation of Commissioner $v$. Liddon ${ }^{78}$ as an example of a successfully litigated brother-sister stock transfer situation in Revenue Ruling 59-9779 suggests that, despite the failure of his earlier attempt, the Commissioner has not abandoned this argument. And in at least one case the taxpayer has argued that what appeared to be a brother-sister stock transfer was really a reorganization. ${ }^{80}$ Applying section 356(a)(2) to the Haserot transaction results in a $\$ 40,584$ dividend. To be accorded such treatment, the Haserot transaction would have to be characterized as a reorganization pursuant to section $368(a)(1)(D)^{81}$ followed by a distribution pursuant to section 356 (a). ${ }^{82}$ Section $354^{83}$ gives content to section

76 In the limited number of distributions incident to reorganizations to which $\S 356$ (b) is applicable, the distribution will be taxed in accordance with $\S 30 \mathrm{I}$.

77 Emma Cramer, 20 T.C. 679, 685 (1953).

78230 F.2d 304 (6th Cir.), cert. denied, 352 U.S. 824 (1956).

79 1959-1 Cum. Bull. 684.

80 Trianon Hotel Co., 30 T.C. 156, 182-84 (1958).

81 "[A] transfer by a corporation of all or a part of its assets to another corporation if immediately after the transfer the transferor, or one or more of its shareholders (including persons who were shareholders immediately before the transfer), or any combination thereof, is in control of the corporation to which the assets are transferred: but only if, in pursuance of the plan, stock or securities of the corporation to which the assets are transsferred are distributed in a transaction which qualifies under section 354,355 , or $356 \ldots . .$.

82 "(1) . . . If - .

(A) section 354 or 355 would apply to an exchange but for the fact that

(B) the property received in the exchange consists not only of property permitted by section 354 or 355 to be received without the recognition of gain but also of other property or money,

then the gain, if any, to the recipient shall be recognized, but in an amount not in excess of the sum of such money and the fair market value of such other property.

"(2) . . . If an exchange is described in paragraph (1) but has the effect of the distribution of a dividend, then there shall be treated as a dividend to each distributee such an amount of the gain recognized under paragraph (1) as is not in excess of his ratable share of the undistributed earnings and profits of the corporation accumulated after February 28 , 1913. The remainder, if any, of the gain recognized under paragraph (1) shall be treated as gain from the exchange of property."

83 "(a)(I) No gain or loss shall be recognized if stock or securities in a corporation a party to a reorganization are, in pursuance of the plan of reorganization, exchanged solely for stock or securities in such corporation or in another corporation a party to the reorganization.... 
$356(a)(1)$. It was with the predecessors of these sections that the Liddon case was concerned.

In Liddon, the taxpayers owned $80 \%$ of the stock of an incorporated Pontiac dealership. The remaining 20\% was held by the corporation's general manager, who wished to sell his interest in the corporation and retire. In order to effectuate his desires, the following transactions occurred: the taxpayers set up a new corporation, Liddon Pontiac, Inc., and contributed $\$ 25,000$ of their personal funds to the corporation in exchange for all of its stock. The old corporation then sold its operating assets to the new corporation and was liquidated. The taxpayers reported their gain on the transaction as a long-term capital gain resulting from the complete liquidation of the old corporation in accordance with section 115(c) of the Internal Revenue Code of 1939. ${ }^{84}$ The Commissioner, however, asserted a deficiency on the ground that the transaction was, in effect, a (D) reorganization in which the "boot" distributed was a dividend taxable under the predecessor of section 356(a)(2). Both the Tax Court and the Sixth Circuit sustained the Commissioner's view of the transaction. They concluded that since the old corporation had transferred part of its assets to the new corporation and immediately thereafter the old corporation's shareholders were in control of the new corporation, the transaction fell precisely within the statutory definition of a (D) reorganization. ${ }^{85}$ Since prior to the transactions the taxpayers held stock in the old corporation and at the completion of the transactions they held stock in the new corporation plus "boot," it was held that, "although there was not a direct exchange of stock in the old corporation for stock in the new, plus 'other property or money,' that was the net effect of what was done." 86 Accordingly, it was concluded, the distributions were governed by the predecessors of sections 354 and $356(a)$.

"(b)(l) Subsection (a) shall not apply to an exchange in pursuance of a plan of reorganization within the meaning of section $368(a)(1)(D)$, unless-

(A) the corporation to which the assets are transferred acquires substantially all of the assets of the transferor of such assets; and

(B) the stock, securities, and other properties received by such transferor, as well as the other properties of such transferor, are distributed in pursuance of the plan of reorganization."

84 Int. Rev. Code of 1939, § 115 (c), as amended, ch. 619, 56 Stat. 841 (1942). Compare INT. REV. CODE OF 1954, § 331 .

85 See Int. Rev. Code of 1939, $\S 112(\mathrm{~g})(1)(\mathrm{D})$, as amended, ch. 247, 53 Stat. 870 (1939). Compare INT. REv. CODE of 1954, $\$ 368(\mathrm{a})(1)(\mathrm{D})$. Patty, Integration of Brother-Sister Corporations, N.Y.U. 16TH INST. ON FED. TAX 409, 427 (1958), suggests that the Liddon transaction would not qualify as a (D) reorganization under the 1954 Code on the ground that the transfer was not one of substantially all the assets. Compare James Armour, Inc., 43 T.C. 295 (1964).

86230 F.2d 304, 307 (6th Cir. 1956). 
In Liddon the court was convinced that the transaction was a reorganization, ${ }^{87}$ so the question was whether the distribution could be viewed as being, in effect, pursuant to the predecessors of sections 354 and 356(a); in Haserot, however, the distribution appears to fit squarely within the terms of sections 354 and 356 (a) if it is agreed that there was a reorganization, so the question would be whether the transaction can be characterized as a (D) reorganization.

There are three requirements for a (D) reorganization: (1) a transfer of assets, (2) control of the transferee corporation following the transaction by the transferor corporation or its shareholders, and (3) a distribution by the transferor corporation to its shareholders of the proceeds of the transaction and all its other property. There is no difficulty fulfilling the second qualification, since after the transaction Haserot owned well over $80 \%$ of the transferee corporation's stock. Nor, assuming that we can find a transfer of assets, would there appear to be a problem with the third requirement. The obstacle thus lies in finding a transfer by the corporation of its assets.

On its face, the transaction was a sale by a shareholder of his stock. Knowing whether, following the transaction, the Haserot Company liquidated Northport and Gypsum and absorbed their assets would be helpful in determining whether this stock transfer can be viewed as an asset sale. Kimbell-Diamond Milling $\mathrm{Co}^{88}$ holds that the purchase of a corporation's stock followed by a rapid liquidation of the acquired corporation will be treated as a purchase of the acquired corporation's assets in cases where the purpose of the acquiring corporation in purchasing the stock was to secure the assets. ${ }^{89}$ In a brother-sister stock transaction in which the acquired corporation is subsequently liquidated, an analogy to the Kimbell-Diamond case suggests that the stock transfer might be viewed as a (D) reorganization. However, the parties' briefs and the Tax Court's opinion do not even suggest that there was

87 That the transaction in Liddon fits precisely within the terms of a (D) reorganization is not as clear as the decision suggests. The statute speaks of a "transfer" of assets. In Pinellas Ice Co. v. Commissioner, 287 U.S. 462 (1932), it was held that a sale of assets for cash did not qualify as a transfer under the statute. The rationale was that the cash sale did not assure the continuity of interest to which the reorganization sections look. This reasoning would seem inapplicable to cash sales where the same interests control both corporations. There seems, then, no objection to viewing a sale of assets to a related corporation as a transfer of assets for the purpose of establishing a (D) reorganization in Liddon, where the taxpayer does own stock in a new corporation upon completion of the transaction. See note 111 infra.

8814 T.C. 74 (1950), aff'd per curiam, 187 F.2d 718 (5th Cir.), cert. denied, 342 U.S. 827 (1951). Legislative adoption of the Kimbell-Diamond rule is reflected in $\S 334(\mathrm{~b})(2)$.

89 While the analysis itself seems in point, it should be noted that facing the court was the far different question of whether the assets should receive a step-up or carryover basis in the hands of the purchaser. 
a liquidation, so one can only assume that none took place. ${ }^{00}$ The question then becomes, in a case such as Haserot, where the acquired corporation is not liquidated, whether the absolute power of the acquiring corporation to effect such a liquidation can be equated with an actual liquidation. Such an equating presents difficulties. The strength of the Kimbell-Diamond analogy is severely undercut by a continuation of the parent-subsidiary relationship which results from a brother-sister stock transfer. Tax, corporate, and business considerations influence the decision as to which is preferable in a given situation. ${ }^{91}$ In United States $v$. Collins ${ }^{22}$ the First Circuit specifically rejected a taxpayer's invitation to ignore these differences in a case involving a brother-sister stock transaction and implied that the differences between a parentsubsidiary relationship and an integrated corporate enterprise require different tax treatment in this situation.

Because the liquidation of the resulting subsidiary in such a case is at the complete discretion of the controlling shareholders of the acquiring corporation, perhaps the most reasonable solution to whether the power to liquidate should be equated with liquidation in fact, and thus to whether the transaction may be viewed as a (D) reorganization, should turn on whether it is the taxpayer or the Commissioner who is seeking to equate the two..93 The taxpayer will do so in order to avoid the impact of section 304 . Since he has the power to liquidate, it is not unreasonable to deny his request to view the enterprise as liquidated when he has decided in favor of the parent-subsidiary relationship and nonliquidation. The Commissioner, on the other hand, will seek to equate

90 It should be noted that many brother-sister stock transfers are followed rapidly by a liquidation of the acquired corporation. See, e.g., Tom Coke Connally, $20 \mathrm{CCH}$ Tax Ct. Mem. 1613 (1961). Trianon Hotel Co., 30 T.C. 156 (1958).

91 See generally Baum, Reshuffing the Stock Interests of Closely Held Brother-Sister Corporations, N.Y.U. 22D INST. ON FED. TAX 677 (1964); Driscoll, Incorporating, in MultiCorporate Form, an Existing Enterprise, N.Y.U. 16TH INST. ON FED. TAX 243 (1958); Terry, Section 304 of the Internal Revenue Code of 1954: Redemptions by Related Corporations, 3 WM. \& MARY L. REv. 457-63 (1962).

92300 F.2d 821, 825-26 (1st Cir. 1962).

93 While the courts have been fairly liberal in allowing the Commissioner to recast transactions which were planned to avoid the literal language of a particular section of the Code while achieving the same effect as would have been achieved had the transaction been cast in the statutory mold, see Commissioner v. Liddon, 230 F.2d 304 (6th Cir.), cert. denied, 352 U.S. 824 (1956), the courts may not allow taxpayers similar leeway. But see Lewis v. Commissioner, 176 F.2d 646 (1st Cir. 1949). In those instances where a taxpayer would take advantage of the reorganization provisions, courts may insist upon a strict compliance with the statutory provisions. See Treas. Reg. \& 1.368-1(b) (1956): "In order to exclude transactions not intended to be included, the specifications of the reorganization provisions of the law are precise. Both the terms of the specifications and their underlying assumptions and purposes must be satisfied in order to entitle the taxpayer to the benefit of the exception from the general rule." 
the two in order to avoid the impact of section 351. The thrust of his argument will be that 351 is not the only section which "provides otherwise" in light of section 302(d); he will argue that section 356(a)(2) does so as well, if the transaction is viewed as a (D) reorganization. The treatment of "boot" under sections 302(d) and 356 (a)(2), even though in the latter the treatment is limited to gain, reflects the same policy considerations. In view of this and of the fact that the "except as otherwise provided" clause appeared to frustrate the Tax Court's desire to tax the Haserot transaction as a dividend, it would not be altogether surprising to see future courts equate the absolute power to liquidate with a liquidation in fact when it is the Commissioner who suggests such a view. The characterization of the transaction as a (D) reorganization thus is likely when the resulting subsidiary is liquidated and possible even when it is not.

Liddon suggests that the reorganization provisions govern when they are in conflict with those sections relating to liquidations. ${ }^{94}$ It has also been recommended that the reorganization provisions take precedence over section 351 when a transaction is within the reach of the literal language of both. ${ }^{95}$ The policy that distributions which have the effect of dividends be consistently taxed as dividends favors the dominance of section 304 over section 351 , the dominance of the reorganization provisions over section 351, and, to a lesser extent, the dominance. of section 304 over the reorganization provisions. Thus, the order of preference should be section 304, the reorganization provisions, and section 351.

While the suggested order of preference seems adequate in light of the existing statutory framework, the distinctions called for are difficult at best and illusory at worst. The more appropriate solution to the problem is a legislative one. There appears to be no sound reason for a distinction between the treatment of "boot" which is incident to a reorganization and that which is incident to a distribution under section 302 , and it is doubtful that "boot" received in those transactions should be treated differently from "boot" which is received in a section 351 transaction. ${ }^{96}$ The bill proposed by the House in 1954 would have

$94230 \mathrm{~F} .2 \mathrm{~d}$ at 307 . See also James Armour, Inc., 43 T.C. 295 (1964).

95 Bittker, Federal Income Taxation of Corporations and Shareholders 373 (1959). See also Subchapter C Advisory Group Revised Report 62.

96 "Doubtful" because the treatment of $\S 351(\mathrm{~b})$ "boot" may reflect a congressional fear that courts would find dividend equivalence too often in $\$ 351$ transactions and thus curtail some desirable corporate adjustments where a corporation expands by purchasing some assets from its controlling shareholder. Such a fear is not to be taken lightly. But additional "safe harbors" or a carefully drafted dividend treatment test would appear to be better solutions than a provision which precludes dividend treatment in all cases. 
treated the "boot" in all three cases in a similar fashion. ${ }^{97}$ More recently the advisory group on subchapter $\mathrm{G}$ has made a suggestion along the same lines..$^{98}$ Legislative elimination of the discontinuities in the treatment of "boot" would provide an equitable solution and eliminate the excessive amount of litigation which arises because of these unfortunate inconsistencies.

\section{Treatment of Asset Withdrawals in Other Forms}

The preceding analysis has been concerned with whether a stock sale within the literal language of section 304 might be viewed as governed by some other Code provision. The converse question arises: whether a transaction which on its face is within some other provision of the Code might be viewed as a stock sale governed by section 304-in other words, may one who controls related corporations extract property without substantial change in control and avoid the impact of section 304 by casting the transaction as other than a sale of his stock in one of the related corporations to the other?

\section{A. The (D) Reorganization}

In the Haserot situation, for example, the taxpayer could have achieved his desired result in the following manner: both Northport and Gypsum could have sold all of their assets to the Haserot Company in exchange for cash and shares in the company and then distributed the cash and shares to their shareholders. ${ }^{99}$ On its face, the transaction would be a (D) reorganization followed by a distribution pursuant to sections 354 and 356. Even if the cash distribution were viewed as having the effect of a distribution of a dividend, only the gain of $\$ 40,584$ would be so taxed. ${ }^{100}$

97 H.R. 8300, 83d Cong., 2d Sess. § 306(b) (1954); see also H.R. REP. No. 1337, 83d Cong., $2 d$ Sess. 39 (1954) ("Your committee's bill is designed to ensure that the same tax consequences result from the different types of transactions which are available to accomplish substantially the same result.").

98 SUBCHAPTER C ADVisory Group REvised REPORT 67-69; see also H.R. 4459, 86th Cong., Ist Sess. § 21 (1959).

99 Because the Haserot Company already owned 1,250 shares of Northport and 2,022 shares of Gypsum, the purchase price would exceed the $\$ 113,490$ paid when only Haserot's shares were purchased. Since the Haserot Company would receive back the excess, however, this distinction would appear to make little difference. (The shares owned by Mabel Carnes would cause a slight increase in the final cost of the transaction to the Haserot Company.).

100 Determining the exact amount taxable as a dividend may involve further complication. This is due to yet another discontinuity in the taxation of distributions having the effect of a dividend. While the full amount of the distribution is subject to being so taxed under $\S 302$ (d), not only is the gain alone subject to such treatment under § 356(a)(2), but the gain is only so taxable to the extent that it does not exceed the shareholder's ratable share of the corporation's accumulated earnings and profits. 
Treatment under sections 354 and 356, rather than under section 304, should be accorded in such a situation. It satisfies the formal requirements for a distribution pursuant to sections 354 and 356, whereas treating it under section 304 would necessitate using the fiction of a stock sale. The Haserot Company now owns the assets directly rather than indirectly through the stock ownership of two subsidiaries, and hence the situation is not comparable to the parent-subsidiary relationship resulting from a brother-sister stock transfer, even though the end result of a (D) reorganization is almost identical to a section 304 stock transfer followed by a liquidation and even though the liquidation in the latter case does not foreclose section 304 treatment. Furthermore, the policy considerations underlying section 304 are also reflected in section 356(a)(2), which taxes as a dividend those distributions pursuant to a (D) reorganization that have the effect of a dividend. Section 356 (a)(2)'s limitation of the amount subject to dividend treatment to the amount of the gain is a call for legislation, not for evoking section 304,101 as a corrective.

Thus, where the taxpayer is willing to forego the parent-subsidiary relationship which would result from a stock transfer, he may use the (D) reorganization ${ }^{102}$ to reduce substantially the impact of section 304 . If there has been no appreciation in the net value of the assets (and, correspondingly, in the value of the stock), use of the (D) reorganization will completely eliminate the impact of section $304 .{ }^{103}$ This inconsistency demonstrates the need for legislative reform of section 356(a)(2) which would eliminate the present restriction limiting dividend treatment to the amount of the gain.

Suppose, however, that either of the following occurred: (1) following the acquisition of the assets, the Haserot Company established two

101 The specific dividend treatment of $\S 356(a)(2)$ would also seem to overcome the argument that in the case where the taxpayer is the sole shareholder of the acquiring corporation the real value of any shares of the acquiring corporation which he receives is zero.

102 The $(C)$ reorganization will also reduce the impact of $\S 304$. The amount of money able to be extracted from the corporate solution in such cases, however, is less.

103 Because $\S 304$ looks to the earnings and profits of the acquiring corporation while $\S 356(a)(2)$ looks to the earnings and profits of the transferor corporation, the (D) reorganization route will also enable the controlling shareholder to avoid the impact of $\S 304$ in those cases where, even though the shareholder has a gain, the transferor corporation has no accumulated or current earnings and profits. Such a case could arise, for example, where a shareholder had purchased his shares when the corporation had a $\$ 2,000,000$ deficit in accumulated earnings and profits, and the deficit had been reduced over the years to a current $\$ 1,000,000$. In order to achieve maximum consistency between $\S \S 304$ and $356(a)(2)$, the latter would have to be amended so that the Commissioner could look to the earnings and profits of either corporation in those cases where they are under common control, as defined in $\S 304$ (c). 
subsidiaries to carry out the former corporations' operations and transferred the former corporations' assets to the new subsidiaries for all of their stock; or (2) prior to the asset acquisition the Haserot Company had created subsidiaries with sufficient cash and Haserot shares to effect the acquisition. In both cases section 304 should apply. In the KimbellDiamond case a stock acquisition was treated as an asset acquisition where securing the assets had been the acquiring corporation's primary objective. The Court's willingness in Kimbell-Diamond to look through the transaction's form and make tax treatment depend rather on its economic effects suggests that, where the corporate structure resulting from a series of transactions is the same as that which would have resulted from a purchase of the stock of the corporations whose assets were acquired, a court might hold that the primary objective of the acquiring corporation was to secure not the assets but the stock of the two other corporations and that, therefore, the transaction should more appropriately be viewed as a sale of the stock covered by section 304.04 Since the risk of such characterization appears great, a careful tax planner should be hesitant to risk reliance on such a route to avoid the impact of section 304 .

\section{B. Liquidation-Reincorporation}

If $A$ owns $100 \%$ of the stock in both corporations $X$ and $Y$, can he avoid the impact of section 304 by having $X$ Corporation liquidate completely, sell all of its assets to $Y$ Corporation and distribute the proceeds of the sale to its shareholders? ${ }^{105}$ Two decisions suggest that he can and that the liquidation provisions will govern. ${ }^{100}$ Again, the chief hurdle to taxing this transaction under section 304 would appear to be the fact that the $X$ Corporation assets are now held directly by $Y$ Corporation rather than by a subsidiary. Where the assets are transferred

104 There would appear to be no difficulty in equating the old and new stock to the assets in Kimbell-Diamond, in spite of the distinction that the assets remained identical throughout.

105 Alternatively, the liquidation-reincorporation could be effected by having $X$ adopt a plan of complete liquidation and distribute its assets to its shareholders; $A$ would, in turn, sell the assets to $Y$ for cash.

106 Emma Cramer, 20 T.C. 679, 685 (1953); Collins v. United States, 193 F. Supp. 602, 609 (D. Mass. 1961), rev'd, 300 F.2d 821 (1st Cir. 1962). See also Kohn, Capital Gain Problems in Particular Areas: Dispositions of Corporate Stock, 12 W. REs. L. REv. 310, 318 (1961) ("Secondly, these provisions do not apply to sales of assets. Accordingly, in the brother-sister situation, if one of the corporations can be liquidated and its assets taken over by the stockholders, and if subsequently, in a separate transaction, the assets are sold to the other corporation for their fair market value, then the transaction would not be a sale or redemption of stock at all, and the stock redemption provisions would not apply."). Compare Lanahan, Redemptions Through Use of Related Corporations, N.Y.U. 18Th INST. ON FED. TAX 741, 756-59 (1960). 
subsequently by the acquiring corporation to a wholly owned subsidiary or directly to a subsidiary which was established just prior to the transaction, the analogy to Kimbell-Diamond compels treating the transaction under section 304 . Where the acquiring corporation retains the assets, however, the question is more difficult. The transaction has enabled $A$ to withdraw a large amount of cash from the corporations with an insubstantial change in his holdings. True, he now controls a single enterprise which holds directly all the assets rather than stock in a corporation which controls the assets through a subsidiary. But such a change in the form of his holdings seems a small price to pay for the extraction of a large amount of cash at capital gain rates.

That the Commissioner will attack such situations and attempt to treat the cash distributions as dividends is clear. James Armour, Inc. ${ }^{107}$ closely parallels the hypothetical with the exception that only the operating assets were sold. In Armour two individuals were the sole shareholders of two corporations, a construction corporation and a corporation owning construction equipment which it leased to the former. The leasing corporation sold most of its operating assets to the construction corporation for cash and an account receivable. The leasing corporation then distributed these proceeds and its liquid and other retained assets to the shareholders in liquidation. The taxpayers urged that the distribution was in pursuance of a plan of complete liquidation and should thus be treated under section $331(a)(1)^{108}$ as payment in exchange for their leasing corporation stock. The asset sale to the construction corporation was viewed as protected by section $337(\mathrm{a}) .{ }^{109}$ The Commissioner, however, asserted a deficiency on the ground that the transaction should be treated as a (D) reorganization with the gain being taxed as a dividend under section 356(a)(2).110 The Tax Court adopted the Commissioner's view of the transaction.

This characterization of the transaction presents, however, several difficulties. While no stock was issued by the acquiring corporation or

10743 T.C. 295 (1964). See also South Texas Warehouse Co., 43 T.C. 540 (1965).

108 "Amounts distributed in complete liquidation of a corporation shall be treated as in full payment in exchange for the stock."

109 "If-

(1) a corporation adopts a plan of complete liquidation on or after June 22, 1954, and

(2) within the 12-month period beginning on the date of the adoption of such plan, all of the assets of the corporation are distributed in complete liquidation, less assets retained to meet claims,

then no gain or loss shall be recognized to such corporation from the sale or exchange by it of property within such 12-month period."

110 A later argument by the Commissioner that part of the distribution might be viewed as a dividend from the acquiring corporation paid through the leasing corporation as a conduit was rejected by the Tax Court. 
received by the shareholders of the liquidating corporation, the Tax Court relied on two cases easily distinguished from Armour, ${ }^{111}$ and held that the section 356(a)(2) stock distribution requirement may be dispensed with in cases involving sole shareholders because the distribution of additional stock to such shareholders is meaningless. The court also held that the transaction might be viewed as a transfer of "substantially all" the assets to the construction corporation, even though only the operating assets were transferred. Here the court relied upon cases which rejected any specific percentage test ${ }^{112}$ and which looked primarily to the operating assets. ${ }^{113}$ More troublesome is the court's position that, since a building which the shareholders received in the liquidation was subsequently leased to the construction corporation, it too could be viewed as being transferred to the acquiring corporation.

Characterizing the transaction as a brother-sister stock transfer governed by section 304 poses fewer problems and possesses several advantages. Since section 304 contains neither a "substantially all" requirement nor a requirement that stock in the acquiring corporation be exchanged, it is far less difficult to view the transaction as a sale of part of the stock in the leasing corporation (equal to the value of the assets transferred) to the construction corporation followed by the liquidation of the acquired corporation. ${ }^{114}$

Section 304 treatment, however, involves the "except as otherwise provided" clause of section 302(d) which the Commissioner has conceded $^{115}$ refers to distributions pursuant to section 331 . To avoid this exception the Commissioner would have to argue that the purported liquidation was a sham for what was, in reality, a brother-sister stock transfer followed by a liquidation. Under this approach the sham transaction would, of course, be disregarded and section 304 alone would govern.

111 In Commissioner v. Morgan, 288 F.2d 676 (3d Cir. 1959), cert. denied, 368 U.S. 836 (1961), reversing 33 T.C. 30 (1959), the court assigned fictional shares to the taxpayer only because some of the assets were transferred without consideration. In Armour, on the other hand, full consideration was received for the assets. The Morgan case is criticized in Lane, supra note 63, at 1233-34. In Commissioner v. Liddon, 230 F.2d 304 (6th Cir.), cert. denied, 352 U.S. 824 (1956), affirming 22 T.C. 1220 (1954), unlike Armour, the taxpayer held shares in a new corporation following the transaction.

112 John G. Moffatt, 42 T.C. 558, appeal docketed, No. 19674-80, 9th Cir., Sept. 28, 1964.

113 Commissioner v. First Nat'l Bank, 104 F.2d 865 (3d Cir.), appeal dismissed, 309 U.S. 691 (1939), reversing Independent Oil Co., 35 B.T.A. 32 (1936).

114 An additional important difference between $\$ 304$ and the reorganization sections should be noted. Dividend treatment in a transaction to which $\$ 304$ applies is limited to the earnings and profits of the acquiring corporation, \& $304(\mathrm{~b})(2)(\mathrm{A})$, while dividend treatment in a reorganization is limited to the earnings and profits of the acquired corporation, $\S 356(\mathrm{a})(2)$.

115 See Brief for Petitioner, p. 21, Henry Mck. Haserot, appeal docketed, No. 16184, 6th Cir., July 7, 1964. Compare Treas. Reg. $\$ 1.302-1$ (a) (1955). 
The potential ramifications of applying section 304 to such a transaction are great. It would be important as a potential weapon with which the Commissioner could attack the Gallagher ${ }^{116}$ type of transaction. The Gallagher facts closely parallel those in Armour with the exceptions that only liquid assets were retained by the liquidating corporation and that the continuing shareholders controlled only $62 \%$ of the corporation whose assets were sold and $72 \%$ of the acquiring corporation. The Tax Court in Gallagher held that there was neither statutory nor judicial authority for the application of the redemption rules of section 302 to the liquidation sale in that case, ${ }^{117}$ and it said that the continuing shareholders' lack of $80 \%$ control $^{118}$ of the acquiring corporation precluded characterizing the transaction as a (D) reorganization.

If the transaction is viewed as a brother-sister stock transfer followed by liquidation, however, section 304 would provide the necessary statutory authority for applying section 302. But under 304(b)(2)(A) only the earnings and profits of the acquiring corporation are examined in determining the amount of the distribution which is viewed as a dividend. In Gallagher the acquiring corporation had been recently established for the sole purpose of acquiring the old corporation's operating assets and thus had no earnings and profits. The advisory group on subchapter $\mathrm{C}$ has suggested amending section 304 to treat the distribution as a dividend where either the acquiring or the acquired corporation has earnings and profits. ${ }^{110}$ Should Congress adopt the subcommittee's recommendation, the Commissioner would probably use section 304 to tax as dividends distributions in the Gallagher type of

116 Joseph C. Gallagher, 39 T.C. I44 (1962), appeals dismissed, Nos. 18844, 18845, 9th Cir., Sept. 19, 1963. Compare Hyman H. Berghash, 43 T.C. 743 (1965). See also H.R. 8300, 83d Cong., 2d Sess. § 357 (1954); H.R. REP. No. 1337, 83d Cong., 2d Sess. A129-31 (1954).

11739 T.C. at 160. Little assistance was given the court by the Commissioner, who, as the court noted, neither cited nor discussed $\$ 302$ in his brief.

118 Section 368(c).

119 SUbChapter C Advisory Group Revised REPORT 13:

Under the amendment proposed in subsection (b) (2) of section 5 , in the brothersister case, the determination of the amount which is a dividend would be made as if the property were distributed by the issuing corporation to the acquixing corporation and immediately thereafter distributed by the acquiring corporation .... This rule will have general application and also will take care of a particular situation brought to the attention of the advisory group. Assume, for example, that individual $\mathrm{A}$ owning all the stock of the $\mathrm{X}$ corporation creates the $\mathrm{Y}$ corporation. $\mathrm{X}$ corporation then borrows money from outside sources to purchase all the stock of the $\mathrm{X}$ corporation from individual $\mathrm{A}$. If the $\mathrm{X}$ corporation is then liquidated into the $Y$ corporation and its assets used to pay off the loan, such a transaction may be treated generally as a reorganization accompanied by a distribution of boot. However, if the X corporation is not liquidated, but merely pays out dividends to the $Y$ corporation to satisfy the loan payments, the transaction would appear to be beyond the scope of the literal language of section 304 . Under the existing statute, the attack on the transaction could only be by use of rules developed judicially to combat tax avoidance. 
situation by characterizing them as distributions pursuant to a brothersister stock transfer. ${ }^{120}$

Even without such legislative action, however, the Commissioner may attempt to use section 304 to reach Gallagher transactions. Through the application of the section 318 attribution rules, brother-sister transactions may also be viewed as parent-subsidiary transactions. ${ }^{121}$ As has been pointed out: "Section 304 recognizes that a corporation may occupy simultaneously the dual status of a subsidiary corporation and a related corporation (other than a subsidiary). This apparent paradox is due to the operation of the attribution rules of stock ownership."122 Congress recognized that the two might overlap and accordingly provided in section $304(a)(1)$ that brother-sister treatment was to yield to parent-subsidiary treatment in such situations.

The most significant difference between brother-sister treatment and parent-subsidiary treatment is that in the latter the distribution may be taxed as a dividend to the extent that there are earnings and profits in either corporation, ${ }^{123}$ whereas in the former, dividend treatment is limited to the extent of the earnings and profits of the acquiring corporation.

The Commissioner could thus attack Gallagher on the ground that, although it most clearly resembles a brother-sister stock transfer, it is also capable of being viewed as a parent-subsidiary stock transfer because of the section 318 attribution rules. Because the statute itself indicates that the latter view is to prevail, the distribution, he would argue, should be treated as a redemption of the stock of the old corpora-

120 Compare Warren \& Antoine, 1965 CGH Fed. Taxation: Current L. \& Practice 714 (discussing Hyman H. Berghash, 43 T.C. 743 (1965)).

121 Section 304(a)(2): "For purposes of sections 302 and 303, if-

(A) in return for property, one corporation acquires from a shareholder of another corporation stock in such other corporation, and

(B) the issuing corporation controls the acquiring corporation,

then such property shall be treated as a distribution in redemption of the stock of the issuing corporation."

122 Diamond, "Brother-Sister Corporations"-Sale of Stock or Other Assets, and Other Problems, U. So. CAL. 1959 TAX INST. 109, 123. Compare Cohen, Silverman, Surrey, Tarleau, \& Warren, The Internal Revenue Code of 1954: Corporate Distributions, Organizations and Reorganizations, 68 HARv. L. REv. 393, 402 (1955). (Footnotes omitted.):

A further difficulty arises from the fact that, by virtue of the attribution rules,

there is an almost complete overlap between the definitions of the two basic situa-

tions covered. Application of the attribution rules to a parent-subsidiary case will usually make it a "brother-sister" case; and application of the rules to a "brothersister" case would seem always to transmute it into a parent-subsidiary case.

See also BitTkER, op. cit. supra note 95, at 236; Lanahan, supra note 106, at 753-54.

123 Section 304(b)(2)(B): "In the case of any acquisition of stock to which subsection (a)(2) of this section applies, the determination of the amount which is a dividend shall be made as if the property were distributed by the acquiring corporation to the issuing corporation and immediately thereafter distributed by the issuing corporation." 
tion. Since in Gallagher the old corporation had earnings and profits, the distribution would thus be taxable as a dividend to those shareholders who fail to qualify for exchange treatment by meeting one of the tests of section 302(b).

The parent-subsidiary characterization arising from the application of the attribution rules, in addition to increasing the earnings and profits to which the Commissioner may look in such transactions, extends the number of situations to which the policy of section 304 might be applied. In a brother-sister transfer the transferor must control both corporations, but in a parent-subsidiary transfer it does not matter that the transferor of stock lacks control of the corporation whose stock is transferred.124 Thus, if in Gallagher the continuing shareholders had controlled less than $50 \%$ of the old corporation, the stock transfer would be subject to dividend treatment under section 304(a)(2) but not under section 304(a)(1).

The courts, however, may be reluctant to adopt the parent-subsidiary characterization in such cases. This may be due in part to the Commissioner's own hesitation. Haserot is but one example of a case in which the Commissioner has chosen to treat as a brother-sister stock transfer a transaction which, through the operation of section 318 , could be viewed under either section $304(\mathrm{a})(1)$ or section 304(a)(2). ${ }^{125}$ Another reason for judicial reluctance may be the widespread criticism that the courts could expect of an interpretation of section 304 which would, to a large extent, read section 304(a)(1) out of existence. As has been noted:

What apparently escaped Congress was that the special operation of the attribution rules of stock ownership has, for purposes of Section 304, become so bizarre that literally there can never be a brother-sister relationship. Consequently, if such literalness is adopted, all of paragraph (l) of Section 304(a) becomes ineffectual. Obviously, Congress did not intend such a legislative aberration ..... ${ }^{126}$

Professor Bittker has suggested that perhaps the intent of the draftsmen was to invoke section 304(a)(2) only in those cases where there was an actual parent-subsidiary relationship. ${ }^{127}$ This suggestion, however,

124 Lanahan, supra note 106, at 753-54.

125 See also Treas. Reg. 1.304-2(c) (1955), as amended, T.D. 6533, 1961-1 CuM. BuLL. 70, where the Treasury Department gives several examples of transactions which it views as being subject to treatment under $\$ 304(a)(1)$.

126 Diamond, supra note 122, at 123. See also Lanahan, supra note 106, at 754 ("such an interpretation would ignore the existence of the statutory rules relating to brother-sister redemptions and, accordingly, would seem unwarranted ...."). The advisory group on subchapter $\mathrm{C}$ has recommended a change to $\S 304$ which would eliminate the overlap. Subchapter C Advisory Group Revised Report 14.

127 Brrrker, op. cit. supra note 95, at 236. 
ignores the specific and unlimited-indeed the expanded-incorporation of section 318 into section 304 by section 304 (c) and the fact that, on occasion, neither the parent-subsidiary nor the brother-sister situation will exist so that dividend treatment may be accorded only by the creation of a parent-subsidiary relationship through the application of section 318. A variation of the Bittker position would allow section 304 (a)(2) to dominate where there is an actual parent-subsidiary relationship, both constructive parent-subsidiary and brother-sister relationships, or only a constructive parent-subsidiary relationship; section 304(a)(1) would dominate where there is either an actual brother-sister relationship and a constructive parent-subsidiary relationship or only a constructive brother-sister relationship. This seems both a rational and desirable approach; nevertheless, it is not compelled by the statutory language.

There would appear to be little trouble in viewing Gallagher as a stock transfer followed by a liquidation. Whether the courts will combine this with the artificial parent-subsidiary relationship of section 304(a)(2), in the face of an actual brother-sister relationship, in order to accord dividend treatment will probably turn on whether the present result in Gallagher is viewed as sufficiently outrageous to justify a literal application of section 304 when to do so would leave a major portion of the statutory structure of the section with little vitality.

Using the specific provision in section 304(a)(1) which states that it is to yield to section 304(a)(2) to increase the reach of section 304 , by treating under 304(a)(2) all transactions which may be so treated through the attribution rules, may actually be most in keeping with the congressional intent in enacting section $304(\mathrm{a})(1)$. The legislative history ${ }^{128}$ reveals that the purpose of the section was merely to extend the tax avoidance provisions dealing with parent-subsidiary transfers to include sales of stock between corporations owned by the same interests. Where a literal reading and application of the section best achieves that end, much can be said for adopting it.

The attractiveness of the parent-subsidiary characterization will increase in direct relation to the increase in transactions patterned after Gallagher. As successive court decisions decline to view such transactions as reorganizations, the Commissioner will be more likely to attempt to tax the transactions under section 304(a)(2).

\section{Choosing Between Dividend and Capital Gain Treatment}

Even where a transaction is concededly governed by section 304, the question remains whether capital gain or ordinary income treatment

128 S. REP. No. 1622, 83d Cong., 2d Sess. 45-46 (1954); Compare H.R. REP. No. 1337, 83d Cong., 2d Sess. 37 (1954). 
will be accorded. Because the section 302(b)(3) "safe harbor" is never available in brother-sister stock transactions and because the application of the $50 \%$ and $80 \%$ tests of section $302(\mathrm{~b})(2)$ is fairly clear-cut, the focus of analysis narrows to whether the transaction can secure capital gain treatment under section 302 (a) by meeting the "not essentially equivalent to a dividend" test of section $302(\mathrm{~b})(1)$. Three of the many problems that have arisen in the application of the dividend equivalency test ${ }^{129}$ are discussed below.

\section{A. Dividend Equivalency and Earnings and Profits}

The impact of the transaction on the acquiring corporation's earnings and profits is relevant in determining whether a brother-sister stock transaction is "essentially equivalent to a dividend." Although the Code and Regulations are silent on the matter, it was considered in the Collins case, where the district court stated:

A dividend essentially involves a distribution of earnings or profits of the corporation to its shareholders. . . . [I]t is . . . essential that these earnings or profits should have been distributed, and thus that there should have been an actual reduction of the corporation's surplus. Of course, the transaction should be carefully scrutinized, since it is possible to have it cast in such a form that the surplus is really reduced although it remains unchanged on paper. That, however, does not appear to be the situation here. The corporation received stock of Permar which was actually worth the $\$ 15,000$ paid for it. It paid out $\$ 15,000$ in cash but received assets worth at least $\$ 15,000$. Conversely the individual shareholders received the cash but parted with property of equal value. Hence there was no real distribution to them of any of the earned surplus of the corporation and hence no dividend. ${ }^{\mathbf{1 3 0}}$

The First Circuit seems to have tacitly accepted the district court's analysis of the impact of a brother-sister transaction upon the earnings and profits account of the acquiring corporation, ${ }^{131}$ but it focused on the economic realities of stock transfers between related corporations:

If a taxpayer owns the entire stock of two corporations and sells his stock in corporation " $A$ " to corporation " $B$ " (extracting cash or property in the process), the economic consequences to the taxpayer are no different than if corporation

129 See generally Nolan, The Uncertain Treatment of Stock Redemptions: A Legislative Proposal, 65 Harv. L. REv. 255 (1961). The application of the dividend equivalency test to the facts of the Haserot case is not considered in this article.

130 Collins v. United States, 193 F. Supp. 602, 608 (D. Mass. 1961), vacated and remanded, 300 F.2d 821 (1st Cir. 1962).

$131300 \mathrm{~F} .2 \mathrm{~d}$ at $823-24$. 
" $\mathrm{B}$ " (the acquiring corporation) had distributed property to him without requiring the surrender of stock, except for the fact (usually devoid of practical consequences) that corporation " $\mathrm{B}$ " now holds the stock of corporation "A."132

Since the court said that section 304 was designed to deal with precisely this situation, it concluded that "the question of the 'fair price' of the subject stock and its residual impact on the surplus account of the acquiring corporation are of little real significance."133 Although the First Gircuit seems correct in holding that a reduction in the earnings and profits of the acquiring corporation has "little real significance" in terms of section 304's broad policy, the district court seems equally correct in holding that the lack of an impact on the corporate earnings and profits is of great significance in determining whether a distribution is "essentially equivalent to a dividend."

Both courts in the Collins case appear to have incorrectly analyzed the impact of a brother-sister stock transaction on the acquiring corporation's earnings and profits. While it is true that the purchase by a corporation of another corporation's stock ordinarily does not affect the earnings and profits of the acquiring corporation, it is equally true that a redemption by a corporation of its own stock does reduce the earnings and profits of the corporation. Since section 304 treats a distribution in a brother-sister stock transaction as a distribution by a corporation in redemption of its own stock, it would appear that a brother-sister stock transaction should also reduce earnings and profits in accordance with sections $312(\mathrm{a})$ and $312(\mathrm{e}) .{ }^{134} \mathrm{It}$ is difficult to view a distribution pursuant to a brother-sister transaction as "essentially

$132 I d$. at 824 .

133 Ibid.

134 Although the fictional characterization given to a brother-sister stock transfer exists by the terms of $\S 304$ itself, only for the purposes of $\S 302$ and not for the purposes of $\S 312(\mathrm{a}), \S 302(\mathrm{~d})$ 's invocation of $\S 301$, which deals with distributions by a corporation with respect to its stock, may be viewed as implying that the testing of the impact of the transaction is to be done under $\S 312$ (a). Section $312(\mathrm{e})$ is, by its very terms, specifically invoked for transactions governed by $\S 302$.

The exact amount by which earnings and profits would be reduced is not clear. The question is not altogether free from doubt even in cases of ordinary stock redemptions. Albrecht, "Dividends" and "Earnings and Profits," 7 TAX L. REv. 157, 200-207 (1952); Edelstein \& Korbel, The Import of Redemption and Liquidation Distributions on Earnings and Profits: Tax Accounting Aberrations Under Section 312(e), 20 TAx L. REv. 479 (1965). Section 312 and the regulations thereunder offer little guidance. In an ordinary stock redemption, each of the about-to-be-redeemed shares reflects, in its value, a portion of the corporation's earnings and profits and a portion of its capital. This is not true in a brother-sister stock transfer, where the value of the stock to be acquired in no way reflects the earnings and profits or capital of the acquiring corporation, thus preventing an allocation between earnings and profits and capital in the same manner as in the case of an ordinary stock redemption. See generally Frost \& Burns, Current Tax Problems While Operating as a Corporation, U. So. CAL. 1958 TAX INST. 117, 159-62. 
equivalent to a dividend" unless there is such an impact on the earnings and profits of the acquiring corporation since treatment of subsequent corporate distributions is governed in large part by the presence of earnings and profits. Without the reduction of earnings and profits characteristic of a dividend, subsequent corporate distributions ordinarily treated as returns of capital might again be taxed as dividends. ${ }^{135}$

Unless the judiciary is willing to permit a reduction of the acquiring corporation's earnings and profits in brother-sister stock transactions, legislative adoption of operative provisions within section 304 will be necessary to avoid anomalous treatment such as that suggested in the Collins transaction.

\section{B. The Significance of the Recipient's Position}

In cases of brother-sister transactions the question of dividend equivalence has traditionally been examined from the viewpoint of the taxpayer. ${ }^{136}$ Even in those cases where the requisite percentages of control can be established only by grouping taxpayers together, it is preferable to examine the tax result by testing the dividend equivalence to each of the taxpayers separately rather than by continuing a group analysis. ${ }^{137}$ If, for example, $A$ owns $40 \%$ of $X$ Corporation and $80 \%$ of $Y$ Corporation while $B$ owns $20 \%$ of $X$ Corporation and $1 \%$ of $Y$ Corporation and both $A$ and $B$ sell all of their $X$ stock to the $Y$ Corporation for cash, the government must view $A$ and $B$ as a group in order to find the control of the $X$ Corporation necessary to call section 304 into play. Having thus invoked 304, however, it seems preferable to analyze the tax results to $A$ and $B$ individually rather than as a group. The distribution to $B$ would qualify for exchange treatment under section $302(\mathrm{~b})(2)$. The distribution to $A$, on the other hand, absent other facts, would appear to

135 If the impact upon earnings and profits in brother-sister stock transfers is similar to that resulting from ordinary stock redemptions then equally incorrect would be the suggestion that when a corporation purchases stock in a related corporation, and the transaction qualifies for $\S 302$ (a) treatment, there is a danger that the acquiring corporation may be taxed under $\S 531$ for improperly accumulating earnings and profits. The tax avoidance possibilities here, while unexplored, could, in some cases, be substantial. For a contrary view see Knapp, Brother-Sister Corporations: Some Stock Problems, N.Y.U. 16rH INST. ON FED. TAX 299, 303 (1958) ("Consequently, in any acquisition by a brother-sister company, the problem of Section 531 should constantly be kept in mind.").

136 It should be noted that a brother-sister stock transaction may bring about far more radical results than those incident to an ordinary stock redemption. The liquidationreincorporation transactions to which $\$ 304$ might be held applicable, for example, would find the old corporation no longer in existence and the minority shareholder no longer a shareholder. That these positions are drastically different from those resulting from the impact of events in an ordinary stock redemption is obvious.

137 This appears to have been done without consideration of the alternative in Radnitz v. United States, 294 F.2d 577 (2d Cir. 1961), affirming per curiam 187 F. Supp. 952 (S.D.N.Y. 1960). 
be "essentially equivalent to a dividend," despite the fact that, unlike the typical dividend situation, $A$ has not merely retained his former interest in the acquired corporation but rather has substantially increased his interest. ${ }^{138}$

\section{The "Net Effect" Test}

Recent cases ${ }^{139}$ suggest that whether a transaction is "essentially equivalent to a dividend" is tested by looking to the "net effect" of the transaction. Under this test the court looks to a large number of factors, such as whether the distribution resulted in any substantial change in ownership or control, whether there was any contraction in the corporate business, whether there was a legitimate business purpose for the transaction, ${ }^{140}$ whether the corporation had sufficient earnings and profits to cover the transaction, whether the impetus for the transaction came from the shareholder or the corporation, and the corporation's past dividend policy. Without stressing the significance of any one of these factors the courts decide whether the "net effect" of the particular combination in the case before them is or is not "essentially equivalent to a dividend." The net effect of the "net effect" test is to provide little guidance for future decisions and to lead many courts merely to list various factors rather than to devote appropriate analysis to each. In analyzing a similar test ${ }^{141}$ in the area of conflict of laws, Professor Currie has offered the following criticism:

The trouble ... is that the quest for "most significant contacts" . . . was not implemented by any standard according to which significance could be determined. "One 'contact' seems to be about as good as another for almost any purpose. The 'contacts' are totted up and a highly subjective fiat is issued to the effect that one group of contacts or the other is the more significant. The reasons for the conclusion are too elusive for objective evaluation." 142

To the extent that the "net effect" test is an alternative to careful

138 There may be some merit to the position that those shares of $X$ which $B$ has sold to $Y$ should be excluded when determining whether $A$ meets the $\S 302(b)(2)$ "safe harbor." Compare Holsey v. Commissioner, 258 F.2d 865 (3d Cir. 1958).

130 See, e.g., Sorem v. Commissioner, 334 F.2d 275 (10th Cir. 1964); Kerr v. Commissioner, 326 F.2d 225 (9th Cir.), cert. denied, 377 U.S. 963 (1964); United States v. Collins, 300 F.2d 821 (1st Cir. 1962); Radnitz v. United States, 294 F.2d 57t (2d Cir. 1961).

140 Compare Kerr v. Commissioner, supra note 139, at 233-36, and Hasbrook v. United States, 343 F.2d 811 (2d Cir.), cert. denied, 34 U.S.L. WeEk 3119 (U.S. Oct. 11, 1965), with Sorem v. Commissioner, 334 F.2d 275, 280 (10th Cir. 1964).

141 The "grouping of contacts" test used to determine the governing tort law when a particular cause of action has "contacts" with more than one state.

142 B. Currie, Comments on Babcock v. Jackson, A Recent Development in Conflict of Laws, 63 CoLuM. L. REv. 1233 (1963). (Footnotes omitted.) 
analysis it is to be condemned. If it is nothing more than another way of stating the question whether a distribution is "essentially equivalent to a dividend," it advances us not at all and serves only to confuse. However, the "net effect" test may reflect a judicial desire to effectuate the broad congressional policy ${ }^{143}$ of section $302(b)(1)$ in the face of its unfortunately rigorous language by importing into that section the more agreeable framing of the test in section $356(a)(2)$, which looks to whether the transaction "has the effect of the distribution of a dividend." That a reading of the test as framed in the latter section would better serve to carry out the policy of section 304 seems beyond doubt. To the extent that judicial pronouncements reflect a desire to import it, they suggest that section $302(b)(1)$ be redrafted to incorporate the section 356(a)(2) wording.

\section{Conclusion}

Section 304, as intended by Congress, can be effective in preventing the distribution at capital gains rates of corporate earnings and profits, when the distribution has the effect of a dividend.

Where the taxpayer transfers stock in one of his controlled corporations to another in return for money or other property, section 304 by its very terms is called into play. Where the taxpayer also receives stock in the acquiring corporation, the transaction falls within the terms of section 351 as well as section 304 . This conflict is best resolved by allowing the broad permissiveness of section 351 to yield to the narrow preventive policy of section 304 . Should the courts hold to the contrary, however, it would still be possible for the Commissioner to assert that the transaction should be viewed as a $(D)$ reorganization taxable in accordance with section 356(a)(2). The argument is persuasive and, again, section 351 should yield.

A liquidation-reincorporation would appear to offer little hope as a means of successfully avoiding the impact of section 304. Indeed, with minor statutory reform or liberal judicial interpretation section 304 becomes a potential vehicle for attacking the growing number of liquidation-reincorporations which have permitted taxpayers to extract substantial liquid assets at capital gains rates, and which the Commissioner has heretofore vigorously opposed with almost no success. Only by carefully casting his transaction in the mold of a (D) reorganization would it appear that the taxpayer can effectively reduce the impact of section 304. This presents an unfortunate inconsistency in the treatment of what is essentially the same transaction and demonstrates the need for

143 S. ReP. No. 1622, 83d Cong., 2d Sess. 234 (1954). Compare Bittrer, Federal INCOME Taxation of Corporations and Shareholders 232-34 (1959) with Herwitz, Cases on Business Planning 418 (temp. ed. 1964). 
eliminating the present restriction in section 356(a)(2) which limits dividend treatment to the amount of the taxpayer's gain.

The application of section 304 requires an analysis of the transaction under section 302 to determine whether the distribution is "essentially equivalent to a dividend." If the distribution is treated as a dividend, an adjustment of the distributing corporation's earnings and profits should be made. Unless the courts allow such a reduction, legislative clarification may be required.

In enacting section 304, Congress was concerned with ensuring that transactions having similar economic effects would receive similar tax treatment. This article has suggested judicial approaches and corrective legislation which would hopefully bring this as yet unattained goal closer to realization. 